\title{
Ethnic Territoriality and the Persistence of Identity: Dutch Settlers in Northwest Iowa, 1869-1880
}

\author{
BRIAN W. BELTMAN
}

SIOUX COUNTY'S DUTCHNESS is almost as strong today as when pioneers established an ethnic colony on Iowa's last frontier 125 years ago. James Paul Allen and Eugene James Turner recently demonstrated this ethnic persistence cartographically by using 1980 census figures. Among counties containing persons of Dutch ancestry, Sioux County held first place in the nation with a Dutch concentration of 55 percent, and the Sioux County towns of Sioux Center and Orange City topped the list of towns with the greatest proportion of Dutch. ${ }^{1}$

Historical statistics confirm that the ethnic snapshot of the Dutch enclave in Sioux County in 1980 represented the product of a long-term consistent development (see table 1). Communities such as Orange City, Sioux Center, Rock Valley, and others were predominant cluster settlements within this subregion. In time the enclave expanded into the adjacent counties of Lyon, $\mathrm{O}^{\prime}$ Brien,

I wish to thank Robert P. Swierenga, R. Dow Bailey, and two anonymous reviewers who read a draft of this paper and provided helpful critiques.

1. James Paul Allen and Eugene James Turner, We the People: An Atlas of America's Ethnic Diversity (New York, 1988), 59. Sioux County was followed by Douglas County, South Dakota ( 34 percent); Ottawa County, Michigan (33 percent); Lyon County, Iowa (23 percent); and Marion County, Iowa (21 percent). After Sioux Center and Orange City came, in rank order, Holland in Ottawa County, Rock Rapids in Lyon County, and Pella in Marion County.

THE ANNALS OF IOWA 55 (Spring 1996). CThe State Historical Society of Iowa, 1996. 
TABLE 1

POPUlATION COMPOSITION OF SIOUX COUNTY, 1870-1925

\begin{tabular}{lrrrrrrr}
\hline Year & \multicolumn{2}{c}{ Total } & \multicolumn{2}{c}{ Native-born } & \multicolumn{2}{c}{ Foreign-born } & \multicolumn{2}{c}{ Dutch-born } \\
& pop. & \multicolumn{1}{c}{$\mathrm{N}$} & \multicolumn{1}{c}{$\%$} & $\mathrm{~N}$ & $\mathrm{~N}$ & $\mathrm{~N}$ & $\%$ \\
\hline 1870 & 576 & 392 & 68.1 & 184 & 31.9 & 133 & 23.1 \\
1875 & $3,220^{\mathrm{a}}$ & 2,067 & 64.2 & 877 & 27.3 & $586^{\mathrm{b}}$ & 18.2 \\
1880 & 5,426 & 3,618 & 66.7 & 1,808 & 33.3 & 1,196 & 22.0 \\
1885 & 11,584 & 7,680 & 66.3 & 3,904 & 33.7 & 1,818 & 15.7 \\
1890 & 18,370 & 12,150 & 66.1 & 6,220 & 33.9 & 3,561 & 19.5 \\
1895 & 21,406 & 14,499 & 67.7 & 6,907 & 32.3 & 4,325 & 20.2 \\
1900 & 23,337 & 16,865 & 72.3 & 6,472 & 27.7 & 4,290 & 18.4 \\
1905 & 24,021 & 17,678 & 73.6 & 6,343 & 26.4 & 4,407 & 18.3 \\
1910 & 25,246 & 18,451 & 73.1 & 6,795 & 26.9 & 5,032 & 19.9 \\
1915 & 25,340 & 18,849 & 74.4 & 6,491 & 25.6 & 5,151 & 20.3 \\
1920 & $26,458^{\mathrm{c}}$ & 20,587 & 77.8 & 5,857 & 22.1 & 4,680 & 17.7 \\
1925 & 26,695 & 21,505 & 80.6 & 5,190 & 19.4 & 4,187 & 15.7 \\
\hline
\end{tabular}

SOURCES: U.S. Censuses, 1870-1920 and Iowa Censuses, 1875-1925.

aThe total population given for Sioux County exceeds the sum of native-born and foreignborn by 276 . The foreign-born population was probably undercounted.

${ }^{b}$ This figure is slightly undercounted. It represents all the Dutch-born in Holland and Nassau Townships, but does not include those residing in Floyd Township. The 63 foreign-born located there in 1875 were largely German Catholics, but about a third were Dutch-born.

The total population includes 14 African Americans who were not included in either the native-born or foreign-born categories.

and Osceola as well as sectors of neighboring states in the environs known as Siouxland.

Despite the thorough narratives of Dutch immigration by historians Jacob Van der Zee, Jacob van Hinte, and Henry S. Lucas, no researchers have identified the precise geographic configuration of this rural ethnic territory at its inception. Nor have scholars explained with coded maps the early spatial expansion of the subregion. ${ }^{2}$ Moreover, although both descriptive historical works and material evidence observable today readily affirm this subculture's Dutchness, certain demographic features of the first settlers remain undefined. This invites classification that helps explain the migration process that began in 1870 and

2. Jacob Van der Zee, The Hollanders of Iowa (Iowa City, 1912); Jacob Van Hinte, Netherlanders in America: A Study of Emigration and Settlement in the Nineteenth and Twentieth Centuries in the United States of America, ed. Robert P. Swierenga (Grand Rapids, MI, 1985); Henry S. Lucas, Netherlanders in America: Dutch Immigration to the United States and Canada, 1789-1950 (Ann Arbor, MI, 1955). 
continued for many years, strengthening the ethnic and agrarian character of the northwest Iowa colony. This augmentation occurred despite irrepressible acculturation that over time worked to Americanize the colony's ethnic inhabitants.

Ethnic persistence is strongly linked to ethnic territoriality. Establishment of an initial contiguous settlement pattern and its subsequent development are critical determinants of an immigrant community's ability to maintain cultural survival and resist assimilation into a host society while adapting to it. Creating and sustaining a land base are just as essential to tribal consciousness and cohesiveness as retaining a group's language, religion, values, and mores, practicing endogamy, or sponsoring parochial schools. All of these practices coalesce to promote ethnic persistence. Ethnic territory, historical geographer D. Aidan McQuillan suggests, "is both cause and effect in explaining the persistence of ethnic traits. ${ }^{\prime 3}$ Further, cultural geographer Wilbur Zelinsky posits a "doctrine of first effective settlement," which holds that special attributes of pioneers are significant in effecting a "viable, self-perpetuating society" through colonial establishment of a new community that is of great consequence for subsequent social and cultural development. "In terms of lasting impact, the activities of a few hundred, or even a score, [of] initial colonizers can mean much more for the cultural geography of place than the contributions of tens of thousands of new immigrants a few generations later."

A sense of place and its relation to ethnic identity often reflect unique circumstances of time and space. The formation and design of the ethnic territory of a group of migrants as well as their demography and kinship ties must be known to understand fully an ethnic community's endurance and vigor. Examining a group's salient attributes and the spatial diffusion of its territory may reveal certain dynamics of rural ethnic settlement

3. D. Aidan McQuillan, "Territory and Ethnic Identity: Some New Measures of an Old Theme in the Cultural Geography of the United States," in James Gibson, ed., European Settlement and Development in North America: Essays on Geographical Change in Honor and Memory of Andrew Clark (Toronto, 1978), 136-69.

4. Wilbur Zelinsky, The Cultural Geography of the United States (1973; reprint, Englewood Cliffs, NJ, 1992), 13-14. 
in the Midwest. ${ }^{5}$ This investigation of the creation and growth of northwest Iowa's Dutch-American enclave during its first decade serves as a case study of ethnic territoriality and the persistence of identity.

THE DUTCH SETTLEMENT in Sioux County was a "daughter colony" of the Dutch settlement surrounding Pella in Marion County, Iowa. Conditions that had led mid-nineteenth-century emigrants to leave the Netherlands - especially the perception that scarce and high-priced land limited opportunities for new farm formation for a rising generation - were being replicated in the Pella area by the late 1860s. Arable land was selling for premium prices of sixty dollars per acre. Tenants faced correspondingly high rents with little possibility of climbing the "agricultural ladder" to become owner-operators. ${ }^{6}$

Such circumstances led a small group of ambitious opportunity-seekers to form a committee in 1869 to establish a new Dutch colony on the northwest Iowa frontier. The leadership group operated under the visionary direction of Henry Hospers, who had been born in Amsterdam, and included Jelle Pelmulder and Sjoerd Aukes Sipma, both from Bornwird, Friesland, and Huibertus Muilenburg and Hendrik Jan Van der Waa, both from Gelderland. New and cheap land especially interested Van der Waa, who had been a tenant in Pella for a generation, and Pel-

5. Despite excellent recent studies of rural immigrant enclaves, scholars have not precisely linked land policy to territoriality nor tracked exact spatial diffusion of enclaves. Important works include Rob Kroes, The Persistence of Ethnicity: Dutch Calvinist Pioneers in Amsterdam, Montana (Urbana and Chicago, 1992); D. Aidan McQuillan, Prevailing over Time: Adjustment on the Kansas Prairies, 1875-1925 (Lincoln, NE, 1990); Yda Schreuder, Dutch Catholic Immigrant Settlement in Wisconsin, 1850-1905 (New York and London, 1989); Robert C. Ostergren, A Community Transplanted: The Trans-Atlantic Experience of a Swedish Immigrant Settlement in the Upper Middle West, 1835-1915 (Madison, WI, 1988); Walter D. Kamphoefner, The Westfalians: From Germany to Missouri (Princeton, 1987); Jon Gjerde, From Peasants to Farmers: The Migration from Balestrand, Norway, to the Upper Middle West (Cambridge, 1985); and John G. Rice, Patterns of Ethnicity in a Minnesota County, 1880-1905 (Umea, Sweden, 1973).

6. Van Hinte, Netherlanders, 465-66; Lucas, Netherlanders in America, 330-35; Van der Zee, Hollanders, 125-26. 
mulder, who had secured land apparently not to his satisfaction. Both eagerly solicited information about land prospects elsewhere, undoubtedly aware of the possibility of acquiring virtually "free land" under the Homestead Act of 1862.

However basic the motivation of land hunger, other impulses also motivated the leadership cadre. The committee members reflected their ethnocultural history by harboring aspirations to colonize. Leadership models from their cultural tradition included Albertus Van Raalte and Hendrik Scholte, Calvinist clergy who had founded the early Dutch enclaves in Michigan and Iowa. Hospers, Sipma, and Van der Waa were all youthful participants among the rank and file who had founded Pella in the late 1840s. Muilenburg and Pelmulder, too, knew the excitement and challenge of migrating and starting anew. ${ }^{8}$ Surely a desire to emulate the cleric colonizers was part of their social psychology; to lead a resettlement endeavor was to become part of something grand and attain fame and stature. For second-generation Dutch-Americans, this mentality evolved into a compulsion to colonize, to create another new refuge for Netherlandic emigrants, to transplant their ethnocultural ways to a new place on the continent as their parents had done transatlantically, and to satisfy the gnawing appetite of land-hungry farmers.

The Dutch in Marion County were also not immune from the contagion of migration and resettlement common to midnineteenth-century America. During the middle decades, thousands of Mormons poured through Iowa on several routes, one of which passed through Pella. Hospers spent time in 1860 in St. Joseph seeing firsthand the droves who funneled through that jumping-off point for the Oregon Trail. Countless Germans, Swedes, Norwegians, Irish, and others transplanted Old World communities in the Midwest contemporaneously with the Pella colony, while thousands of Americans replicated, sometimes in

7. Van Hinte, Netherlanders, 470-72; Lucas, Netherlanders in America, 333-36; Van der Zee, Hollanders, 122, 127-31,394n; G. Nelson Nieuwenhuis, Siouxland: A History of Sioux County (Orange City, 1983), 61-63; Charles L. Dyke, The Story of Sioux County (Orange City, 1942), 8-10.

8. Van Hinte, Netherlanders, chaps. 8 and 9; Lucas, Netherlanders in America, chaps. 3 and 4 . 
less structured ways, old eastern villages and neighborhoods. ${ }^{9}$ And periodically from Pella some new land seekers outmigrated to Kansas, Nebraska, and Texas in the 1860s. Most important to the future of northwest Iowa was the journey of about fifteen families to Oregon in 1864. Led by Cornelius Jongewaard and including a kinship group of Van der Meers and Van den Boses, most of them stayed in Oregon only five years or less, then returned to Pella between 1866 and 1869, only to join the pioneers to Sioux County in $1870 .^{10}$

In the spring of 1869 the planned colony's leaders (excluding Hospers) formed a scouting party that returned from northwest Iowa with favorable reports on settlement prospects in Buena Vista and Cherokee Counties. In Pella the response was immediate: 82 persons joined a kolonisatie vereeninging (association for colonization) and subscribed for 17,920 acres ( 28 sections) in the envisioned settlement. In June, Hospers, the editor of Pella's Weekblad, published a list of 86 individuals desiring homesteads and 13 others who agreed to buy outright land tracts of 80 to 480 acres. The association then formed a new leadership committee authorized to choose an alternate location if the Cherokee County area proved unacceptable. That committee would

9. Van Hinte, Netherlanders, 464-71; Van der Zee, Hollanders, 199. Besides the sources cited above in note 6 , studies of immigrant transplantations include Brian W. Beltman, Dutch Farmer in the Missouri Valley: The Life and Letters of Ulbe Eringa, 1866-1950 (Urbana and Chicago, 1996); idem, "Ethnic Persistence and Change: The Experience of a Dutch-American Family in Rural Iowa," Annals of Iowa 52 (1993), 1-49; Charles Tilly, "Transplanted Networks," in Virginia Yans-McLaughlin, ed., Immigration Reconsidered: History, Sociology, and Politics (New York, 1990); Robert P. Swierenga, "Settlement of the Old Northwest: Ethnic Pluralism in a Featureless Plain," Journal of the Early Republic 9 (1989), 73-105; Frederick C. Luebke, "Ethnic Group Settlement on the Great Plains," Western Historical Quarterly 8 (1977), 405-30. For moving Americans, see Kathleen Neils Conzen, "A Saga of Families," in Clyde A. Milner II, Carol A. O'Connor, and Martha A. Sandweiss, eds., The Oxford History of the America West (New York, 1994), 315-57; John C. Hudson, "North American Origins of Middlewestern Frontier Populations," Annals of the Association of America Geographers 78 (1988), 395-413.

10. Dyke, Story, 402-12, 429-30, 461-62, 414, 566; Lucas, Netherlanders in America, 334; Federal Manuscript Population Census for 1870; Thomas Noteboom, "Holland Township: The Settlement, Distribution and History of its Land" (student paper, n.d., Dutch Heritage Collection, Northwestern College, Orange City), 4. 
also select and arrange the allocation of sections for homesteads to subscribers by lot with particular attention to allowing adequate space for kinfolk to cluster near each other. Finally, they were to designate a town site covering up to 240 acres in which lots were to be priced at ten dollars each. The new committee included Leendert Van der Meer and Dirk Van den Bos, cousins who were part of a large family network in Marion County, as well as Hospers and Van der Waa. ${ }^{11}$

When the second committee made its excursion to northwest Iowa in mid-1869, they found the Cherokee County land a frenzied speculators' market in anticipation of the Dutch project. Learning from government land officials at Sioux City of available land in Sioux and Lyon Counties, some of it still in the public domain and some of it part of railroad land grants, the four men altered their course. In company with a surveyor, they began at the southern border of Sioux County to measure the land according to the system devised under the Land Ordinance of 1785 . They marked out the western limit of the 36section township later to be designated Nassau and then proceeded north, locating the western border of future Holland Township and two miles of the border of future Capel Township. Having penetrated 14 miles into Sioux County, they turned southward until they reached the future township boundary between Holland and Nassau. They also traveled eastward to the Floyd River. ${ }^{12}$

The land they were crossing was part of the watershed of the main channel of the Floyd River and its West Branch, a prairie corridor of glacial drift with a mantle of black loess several feet deep. The topsoil, technically known as Marshall silt loam, was rich in humus and covered with tough sod that supported grasses that in places reached to the shoulders of men and horses. Except along the river banks, the immense prairie was treeless, one great swell of land as far as the eye could see and of such fertility that few could imagine its eventual produc-

11. Van Hinte, Netherlanders, 472-74; Lucas, Netherlanders in America, 337; Van der Zee, Hollanders, 131-32; Dyke, Story, 14-15; Nieuwenhuis, Siouxland, 63. 12. Van Hinte, Netherlanders, 473; Lucas, Netherlanders in America, 337-38; Van der Zee, Hollanders, 132-33; Dyke, Story, 11-23; Nieuwenhuis, Siouxland, 63-65. 
tivity. In this geography of abundance lay the region's destiny (although a critic taking the long view would say its demise). On an undulating ridgeland forming the divide between the two water courses, the land seekers selected a site on the northeast quarter of section 32 of future Holland Township for the central village of their planned colony. Their survey work done, the group returned to the land office in Sioux City to legalize their claim to 29 sections of the public domain available for homesteading and to draw lots assigning sections numbered according to the federal survey system to the members of the association. ${ }^{13}$

This simple but dramatic action created the initial Dutch enclave in Sioux County, the place essential to a sense of ethnic territoriality. Unnamed yet in 1869, on June 6, 1870, the County Board of Supervisors responded to a motion by Dutch-American petitioners to designate ranges 43,44 , and 45 of Township 95 as Holland Township and the same three ranges of Township 94 as Nassau Township (see map 1). ${ }^{14}$ In sum, this planned colonization was the product of careful foresight and organization, and the element of risk had been characteristically muted by conservative objectives and manageable methods: the group had sought and obtained good Iowa land for farming under the most liberal land policy then existing in nineteenth-century America.

WHO WERE THE PIONEERS who were willing to leave the settled Dutch community around Pella and invest their capital in and commit themselves to a new settlement in northwest Iowa? The list published in Pella's Weekblad in June 1869 named 99 colonists who were planning to relocate in Cherokee County, an area never occupied by Dutch migrants. The federal manuscript population census taken one year later identified a total of 253 persons living in the newly transplanted Dutch enclave

13. Van Hinte, Netherlanders, 473; Lucas, Netherlanders in America, 338; Van der Zee, Hollanders, 133; Nieuwenhuis, Siouxland, 65; Dyke, Story, 24; Noteboom, "Holland Township," 15. For a technical discussion of soil type, see W. H. Stevenson and P. E. Brown, Soil Survey of Iowa, Report No. 6 (Ames, 1918).

14. Nieuwenhuis, Siouxland, 66; Noteboom, "Holland Township," 15. 
MAP 1

SIOUX COUNTY AND ITS SUBDIVISIONS IN 1870

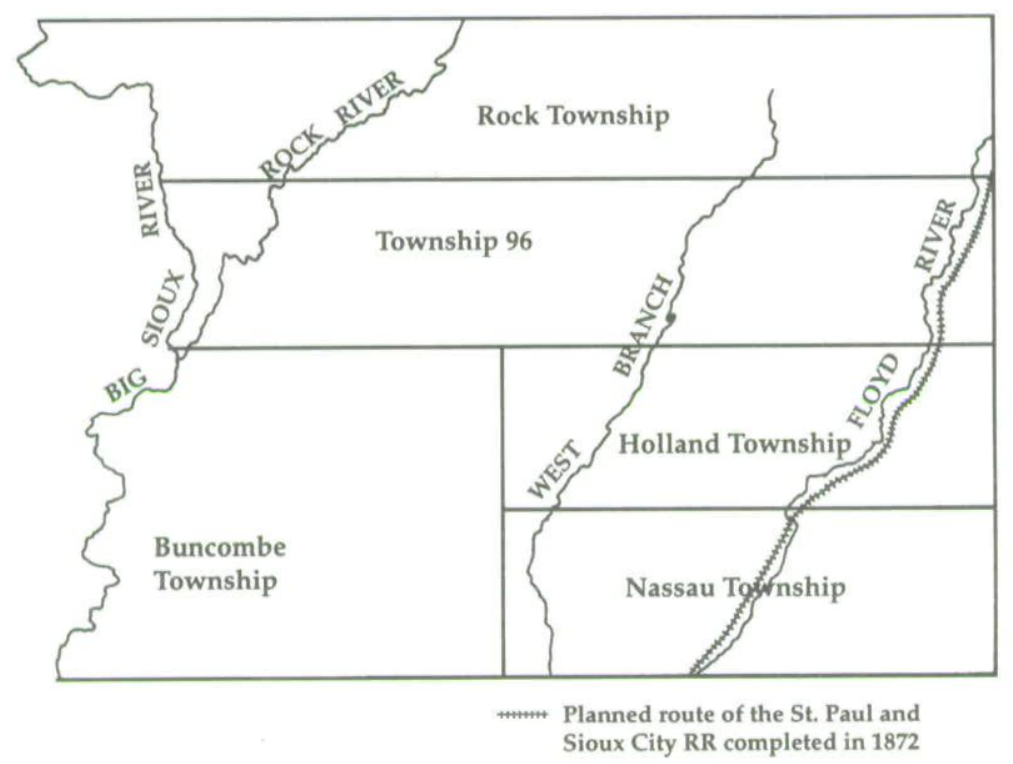

in Sioux County who actually fulfilled the colonial strategy. ${ }^{15}$ This group comprised 40 family households - 36 two-parent families (four of which had no children), two families consisting of widowers with children, one of a widow with children, and one household of two brothers and an older single female housekeeper. Nine independent persons were augmentations within these households. This group also included 23 single adult males (age 21 and older) and five single adult females. The average age of the male household heads of the 36 nuclear

15. Information in the next several paragraphs is derived from the Federal Manuscript Population Census for 1870; and Robert P. Swierenga, Dutch Emigrants to the United States, South Africa, South America, and Southeast Asia, 1835-1880: An Alphabetical Listing of Household Heads and Independent Persons (Wilmington, DE, 1983). I compiled a list of 75 Dutch pioneers homesteading in Sioux County in 1870. The list includes each person's age, the township and section where they located their homestead, their place of Dutch residency (by municipality and province where possible) prior to their emigration to the Pella area, and the date they emigrated. That list is in the production files for this article in the editorial office of the Annals of Iowa at the State Historical Society of Iowa's Centennial Building in Iowa City. 
families was 42 and for the female household heads was 38 . The average age of the single adult males was 29 and for the single females was 38 . The number of children per family household with children averaged 4.6 , and the average age of these 161 children was $10 .^{16}$

Every household head or single adult was Netherlandsborn and an immigrant transplant through Marion County, Iowa, except for the Tjeerd Heemstra family who, although Holland-born, came from Vriesland, Michigan, independent of the caravans from Pella. All of the children were born in the Netherlands or Iowa, except for one of the Heemstra offspring (Michigan-born) and ten children of six of the families that had resided in Oregon between 1864 and 1869. Several families were related to one another and bore common surnames, more were related through marriage, a few were paired as father and son or as brothers, and most were neighbors of varying degree from the Pella area. Except for a blacksmith and a surveyor, all identified their occupations as farmers, farm laborers, or housekeepers.

This profile suggests that the Dutch-American pioneers in northwest Iowa in 1870 generally fit into one of three categories. One type consisted of more than thirty family households headed by adults who initially came to Iowa from the Netherlands either as minors within emigrating families or as young married couples. The former matured in the Pella settlement, married endogamously, and started families in the 1850s and 1860s. The latter began or increased their families during those years. All were part of the first wave of nineteenth-century Dutch emigration to America that lasted from 1847 to 1857 and was largely a rural folk movement. ${ }^{17}$ By 1869 , many of these family heads were

16. Compare this demographic profile to that of Iowa pioneers generally in Allan G. Bogue, From Prairie to Corn Belt: Farming on the Illinois and Iowa Prairies in the Nineteenth Century (Chicago, 1963), 22-25, and, more specifically, of Dutch immigrants in Swierenga, "Dutch Immigrant Demography, 1820 1880," Journal of Family History 5 (Winter 1980), 390-405.

17. I cite here only several of the numerous articles by Robert P. Swierenga that provide invaluable insight into the structural composition of Dutch immigration to the United States, including discussion of the "wave" pattern and its characteristics: "Dutch Immigrant Demography"; "Dutch International Labour Migration to North America in the Nineteenth Century," in Herman Ganzevoort and Mark Boekelman, eds., Dutch Immigration to North America 
middle-aged and had four or five children. These large families provided a sizable domestic work force for agricultural production on a frontier requiring much manual labor. The rising generation also gave urgency to founding a colony with a land base adequate to provide for its future needs.

Two examples illustrate this first classification. In 1849 Dirk Van den Bos emigrated at age 14 with his parents and three siblings from Geervliet, Zuid Holland, to Iowa. In the Pella colony he married a Dutch-born woman named Johanna, who died after the birth of their son. Dirk then married Christiana, and they had three children. By 1870, when they were 35 and 34 , they were raising six children, ranging in age from thirteen to one. The two oldest children were a nephew and niece orphaned when their parents died in Oregon. Hermanus and Hendrika Luymes, ages 45 and 44 in 1870, came from Elst, Gelderland, to Iowa in 1856 with two children. In Marion County they had four more children who by 1870 ranged in age from twenty to three. Such first-wave Dutch emigrants as these opted to transplant again to northwest Iowa and farm homesteads.

A second group among the 1870 colonizers encompassed the 17 single males. A few of these were farm laborers, but more were ambitious young farmers and ready candidates for family formation. For example, the De Jong brothers, Pieter and Koenraad, ages 23 and 21, were of the Koenraad de Jong family, who had emigrated in 1847 from Schoonhoven, Zuid Holland, to Pella. The Rysdam brothers, Wijnand and Gerrit, ages 28 and 24, left Utrecht in 1855 as dependents within their family. They were also experienced veterans of overland travel since their family was among those who went from Pella to Oregon and back in the 1860s. By 1870 these independent young men were ready to homestead in Sioux County.

A third type among the settlers comprised the nearly twenty households who were more recent emigrants, part of the second wave of Dutch emigration to America lasting from 1865 to 1873.

(Toronto, 1983), 1-34; "Local Patterns of Dutch Migration to the United States in the Mid-Nineteenth Century," in Rudolph J. Vecoli and Suzanne M. Sinke, eds., A Century of European Migrations, 1830-1930 (Urbana and Chicago, 1991), 134-57; The Dutch Transplanting in the Upper Middle West (Marshall, MN, 1991). 
This post-Civil War group came to Marion County only to face constricted opportunities endemic to that well-settled enclave, yet hoping in time to capitalize on the "free land" policy of the Homestead Act that drew so many to the rural heartland. It was, however, a mixed group. Some of its families were small and newly formed. Harke and Griet Boersma, ages 28 and 24 in 1870, came from Kollumberland, Friesland, to Pella in 1867 and had their first child in 1869, the same year that Harke's brother Lubbert, his wife, and their one child arrived. The two Boersma families homesteaded near each other in Sioux County. The case of the Ruisches illustrates a larger postwar family emigration: Duije and Nielje, ages 45 and 40 in 1870, came in 1867 from Leek, Groningen, to Pella with five children, the oldest 10. Their sixth child, Gerrit, was two years old when they moved to Sioux County.

Most of the Dutch-American settlers had adequate resources to facilitate internal migration. The census taker of 1870 compiled information on 37 Dutch farmers in Holland and Nassau Townships, detailing the cash value of their farmland, equipment, livestock, and personal property. All were homesteaders just beginning the five-year residency requirement to obtain clear title, so the value placed on land was yet an unrealized increment. Nonetheless, the average net worth of $\$ 891$ derived from the aggregate figures defines the financial standing of the 1870 pioneers and relates to their ability to meet successfully the initial expenses of farm-making. (For a summary of the pioneers' material conditions in their first season of settlement, see table 2).

None of the pioneers were wealthy and none were impoverished, but their possessions did range from sparse to substantial. For example, widower Cornelius Lakeman, age 54, homesteaded 80 acres in Sioux County with his two daughters, 15 and 4. Lakeman had a mobile past, moving from the Netherlands to Marion County in 1847 and then trekking with the Van der Meer clan to Oregon in 1864, where presumably his wife died. He returned to Pella before moving to northwest Iowa. The estimated value of his Sioux County farm and equipment in 1870 was $\$ 120$ and his personal property $\$ 200$. His only other possession was a cow valued at $\$ 50$. In contrast, Leendert Van der Meer, another emigrant to Pella who had ventured to the Pacific Northwest and back in the 1860s, started farming 80 
TABLE 2

AGRICULTURAL STATUS OF DUTCH FARMERS

IN SIOUX COUNTY, 1870

\begin{tabular}{lr}
\hline Acres of land (improved) & 20.9 \\
Acres of land (unimproved) & 55.9 \\
Total acres of land & 76.8 \\
Value of farm & $\$ 241$ \\
Value of livestock & $\$ 383$ \\
Value of personal property & $\$ 250$ \\
Horses & 1.9 \\
Oxen & 1.0 \\
Milk cows & 1.9 \\
Other cattle & 2.0 \\
Sheep & 1.0 \\
Swine & 0.4 \\
\hline
\end{tabular}

SOURCE: Federal Manuscript Agricultural Census for 1870.

NOTE: All figures represent the average per farm value $(\mathrm{N}=37)$.

acres in Sioux County at age 39 with a farm and equipment worth \$320; four horses, four milk cows, four sheep, two pigs, and 26 head of cattle all valued at $\$ 900$; and personal property amounting to $\$ 200$. His household consisted of his wife, their five children, two orphaned nephews, and an adult female "housekeeper." 18

Regardless of type or financial means, the Dutch pioneers of 1870 were eager to relocate, and their overall modest financial prospectus illustrates why the opportunity offered by the Homestead Act was particularly appealing and eagerly acted upon. Some hoped to move from tenant status to land ownership where homesteads were available. Others wanted to acquire inexpensive and fertile new land of perceived greater productiveness. Some simply wished to start anew in an unsettled area where the prospect of farming on a comparatively larger and more prosperous scale was a realistic possibility. They were not failures drifting from an old community under-

18. For comparison, economic historians have estimated that in 1850 a farmmaker needed nearly $\$ 1,000$ to make a go of a 40 -acre farm, and in 1860 more than $\$ 1,700$ was needed for an 80 -acre place, although in a less settled area like Iowa perhaps $\$ 800$ to $\$ 1,300$ was sufficient to start farming. See Clarence H. Danhof, "Farm-making Costs and the 'Safety Valve': 1850-1860," Journal of Political Economy 49 (1941), 317-59; Jeremy Atack, "Farm and Farm-Making Costs Revisited," Agricultural History 56 (1982), 663-76. 
going fragmentation, but rather opportunity-seekers who left an area where maturity and stabilization limited opportunity. They chose to move elsewhere to fulfill their ambitions and needs within the security of an intentional community of kith and kin, where ethnocultural homogeneity and shared socioeconomic standards and expectations were linked to the tradition of family farming. ${ }^{19}$

THIS TRANSPLANTED ETHNIC ENCLAVE of family units occupied "free land" in southeastern Sioux County. They settled on surveyed sections of land that were contiguous to provide convenient but not crowded clustering for community affinity. They were careful to allow considerable surplus and unoccupied land within each section for future acquisition by relatives, friends, or the next generation. The association's allotment process was originally designed to facilitate such growth. ${ }^{20}$ At the same time, however, the colony had to accommodate that strategy and future expansion in the surrounding area to the realities of the land market and other constraints that impinged on their objectives.

Indeed, the acres available for homesteading in the ethnic territory were significantly limited already by 1869-70. In 1856 Congress, in keeping with a practice begun under a land grant to the Illinois Central Railroad in the 1850s, assigned the Iowa Falls and Sioux City Railroad a land grant of all odd-numbered sections for six miles on both sides of the railroad right-of-way. Although this railroad, which was in service by July 1870, did not run through Sioux County, it did pass through the eastern part of adjacent Plymouth County, within six miles of the southern border of Sioux County, before heading south to Sioux City

19. For the view that migrants were those who "failed and pushed on," see John M. Faragher, "Open-Country Community: Sugar-Creek, Illinois, 18201850," in Steven Hahn and Jonathan Prude, eds., The Countryside in the Age of Capitalist Transformation (Chapel Hill, 1985), 252.

20. See the details of the association's mandate as described in Van Hinte, Netherlanders, 473-74; Lucas, Netherlanders in America, 338; Van der Zee, Hollanders, 134-35; and especially Hendrik J. Van der Waa, "The Beginning of the Colony," Standard Historical Atlas of Sioux County, Iowa (Chicago, 1908), section 2, 1-2, which makes this expansion strategy clear. 
from LeMars. In 1864 the St. Paul and Sioux City Railroad, which was to follow the Floyd River through Sioux County, obtained a donation of land of all the odd-numbered sections for ten miles on both sides of its right-of-way. This track was completed through Sioux County in October 1872. Standard railroad land grant procedure stipulated that if the federal government could not fill the quota within the designated railroad zone, companies could select indemnity or lieu sections. The St. Paul and Sioux City Railroad could claim substitute land within 20 miles of the track line, while the Iowa Falls and Sioux City Railroad had access to land within 15 miles of its track. As a result, railroad land of the latter reached well into southern Sioux County. All of this land set aside to subsidize railroad construction made half of the public domain unavailable for Dutch-Americans to homestead in Sioux County. Additional even-numbered sections - several thousand acres of prairie in greater Holland and Nassau Townships - were not available to Dutch homesteaders because they were assigned to the Des Moines Valley Railroad Company after its original grant lands were contested. ${ }^{21}$

Other even-numbered sections in Sioux County were unavailable for homesteading because of the provision in the Land Ordinance of 1785 that the sale of section 16 in each township was to fund public education. Iowa law controlled the minimum price for this school land, which by 1870 was six dollars per acre, a charge considerably above the "free land" of the Homestead Act that generally required only a ten-dollar filing fee and a five-year residency to secure clear title. So the sixdollar school land remained untouched by frugal Dutch buyers for a decade; only then did the land market make school land no longer unreasonably expensive. ${ }^{22}$

21. Roscoe L. Lokken, Iowa Public Land Disposal (1942; reprint, Iowa City, 1972), 210-61; Noteboom, "Holland Township," 12-13; Van Hinte, Netherlanders, 473; Van der Zee, Hollanders, 134-35; William Silag, "The Conquest of the Hinterland: Railroads and Capitalists in Northwest Iowa after the Civil War," Annals of Iowa 50 (1990), 475-506; John Bell Rae, The Development of Railway Land Subsidy Policy in the United States (1936; reprint, New York, 1979), 76-80; Paul Wallace Gates, The Illinois Central Railroad and Its Colonization Work (Cambridge, 1934); Lucas, Netherlanders in America, 182-83.

22. Lokken, Iowa Public Land, 154-57; Noteboom, "Holland Township," 11-12. 
The public domain was also diminished through swamp land grants. In 1850 Congress began providing tracts of wetlands to states for reclamation purposes. States applied for millions of acres deemed swampy, often by criteria that was dubious at best and fraudulent at worst. In Holland Township two hundred acres were deemed swamp land. Forty acres of this tract were sold at public auction in August 1870 and produced sixty dollars for the Sioux County school fund. ${ }^{23}$

Finally, environmental constraints, coupled with common sense and the simultaneous founding of another ethnic enclave, eliminated one other portion of Sioux County prairie from the colonists' initial occupation. German Catholics who arrived from Jackson County, Iowa, in May 1870 settled on sections of land lying east of the Floyd River in future Nassau, Floyd, and East Orange Townships. In the 1870 s the Floyd was yet unmuddied by agricultural runoff and was good to fish and swim in, but was not easy to cross with horses and wagons. Although not a watercourse of enormous dimensions, the local channel required difficult fording and was not easily bridged. As a result, the Floyd formed a geocultural boundary on the southeastern side of the early Dutch colony. ${ }^{24}$

The ethnic territory was not strictly confined, however, to the prairie corridor between the Floyd and its West Branch. That branch eight to ten miles to the west served less as a natural limit, for it was comparatively easy to ford. Nor did any clearly defined ethnoreligious group like the German Catholics form a competing enclave across the West Branch. Nonetheless, one Dutch wit placed a sign by an early bridge across the creek that stated, "Here is the end of civilization." ${ }^{25}$ Beyond the humor, the sign indicates that Dutch residents viewed their enclave in territorial terms.

23. Lokken, Iowa Public Land, 180-209; Noteboom, "Holland Township," 13-14; Margaret Beattie Bogue, "Swamp Land Act and Wet Land Utilization in Illinois, 1850-1890," Agricultural History 25 (1951), 169-80.

24. Nieuwenhuis, Siouxland, 78-79. For a description of the 10-feet deep Floyd, see Dyke, Story, 78-79. Interestingly, 125 years of history has not changed the geocultural border; today few of Dutch stock are found in the southeastern corner of Sioux County.

25. Nieuwenhuis, Siouxland, 80. 


\section{MAP 2}

DUTCH HOMESTEADS BY SECTION IN 1870

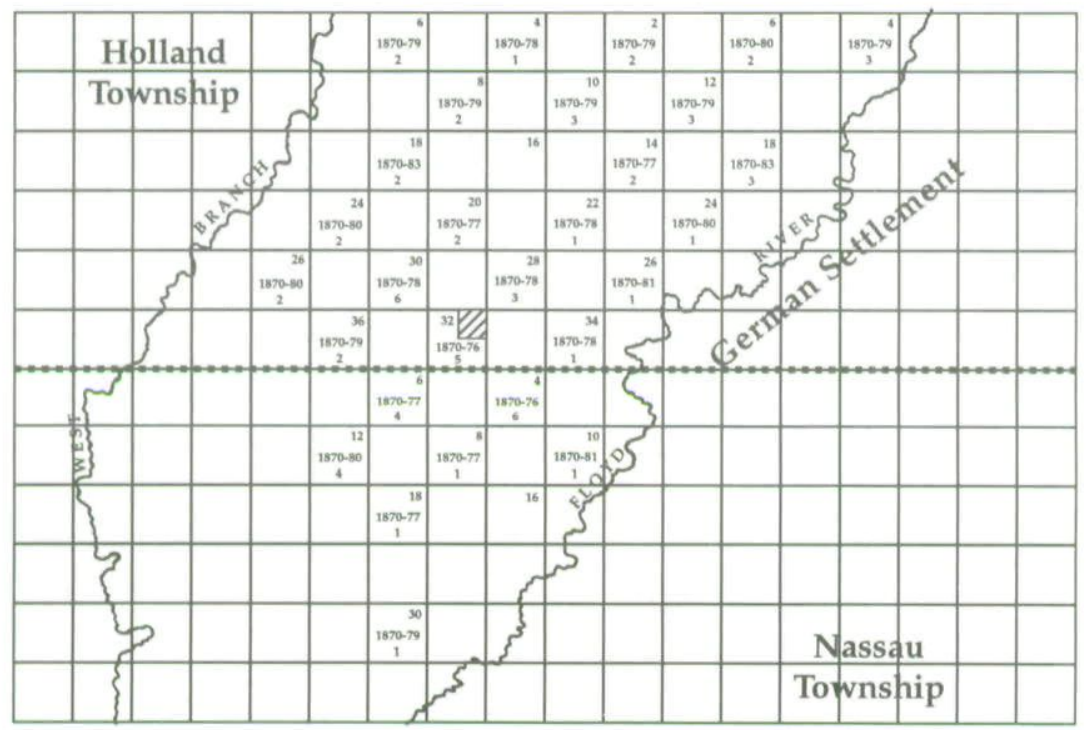

$\square$ Townsite of Orange City

When all of these exemptions and qualifications are applied to the area in which the Dutch-Americans were planning in 1869 to acquire fee-simple or direct purchase parcels, the true rural land base for the initial Dutch ethnic territory in Sioux County emerges. Map 2 shows a geographic checkerboard featuring the 29 sections (numbered in the upper right-hand corner according to the government survey system) in which farmers began working their homesteads in 1870 . The range of years on these designated sections indicates the time span necessary to take up all of the acreage within a given section. The number below the dates on each section reveals how many individual homesteads were patented by settlers in 1870 . Without exception these Dutch-Americans alienated eighty-acre tracts of "free land" from the public domain. This common size was set by the Homestead Act, which stipulated that claims within the confines of railroad land grants were restricted to eightyacre parcels priced at a minimum of $\$ 2.50$ per acre if purchased outright. If settlers had the cash, they could purchase addi- 
tional land that was for sale from whatever source and with no size limits, but none of the Sioux County Dutch did so in the 1870s. Civil War veterans, moreover, were entitled to an additional eighty acres for homesteading. Only ex-soldier Henry Van der Waa exercised this option. ${ }^{26}$

Here, then, in that verdant spring, the pioneers and their households came in five wagon caravans from Pella, built dugouts, sod houses, or wooden shanties, and began breaking the prairie turf on their claims. ${ }^{27}$ This Dutch colonial effort was a highly organized group migration of families and neighbors, bound by ethnicity, kinship, religion, language, customs, and folk history. They sought to replicate the Pella Dutch community and all of its cultural attributes in Sioux County, and unlike some colonization plantings, the seedling fell on fertile ground, sprouted, thrived, and bore fruit. The Dutch colony was a product of planning, vision, and faith, and it materialized into a discrete and unique geographic territory that was defined by its ruralness, its ethnicity, and its compact contiguity to the extent permitted by available public land.

This planned process of rural settlement on detached family farms did not recreate Old World agricultural villages, where farmers lived in cluster settlements and tilled acres in outlying strips or patches. ${ }^{28}$ That agricultural approach was lost a gen-

26. Transfer Books for Holland and Nassau Townships, Sioux County Courthouse, Orange City.The 80 -acre homestead restriction within railroad land grants lasted until 1879; thereafter claimants could increase this to 160 acres. On the Homestead Act of 1862 and other land laws, see generally Paul Wallace Gates and Robert W. Swenson, History of Public Land Law Development (Washington, DC, 1968).

27. Descriptive accounts of initial settlement are found in Van Hinte, Netherlanders, 475-77; Lucas, Netherlanders in America, 339-42; Van der Zee, Hollanders, 140-44; Dyke, Story, 25-41; and Nieuwenhuis, Siouxland, 67.

28. Audrey M. Lambert, The Making of the Dutch Landscape: An Historical Geography of the Netherlands (London and New York, 1971); Royden K. Loewen, Family, Church, and Market: A Mennonite Community in the Old and the New Worlds, 1850-1930 (Urbana and Chicago, 1993); John Hostetler, Amish Society (Baltimore, 1980); idem, The Hutterites in North America (New York, 1980); Elmer Schwieder and Dorothy Schwieder, A Peculiar People: Iowa's Old Order Amish (Ames, 1975). Only in the most conservative communal rural settlements, such as those of the Amish, Mennonites, or Hutterites, did Old World village farming survive in the American heartland. The Dutch colony, although 
eration earlier in the initial New World transplantation; it was long forgotten by the time of the intrastate transplanting to northwest Iowa. There farmers took up the land in individualized allotments, as was the standard practice of acculturated Dutch-Americans in Marion County. Farmsteads located in the open country dotted the prairie landscape, fitting into the grid pattern of the land survey system. As long as clear title was attained and taxes were paid, American jurisprudence guaranteed that these "sovereign" family farms would belong to the owners and their heirs in perpetuity. Despite the individualized system of property ownership, the settlement arrangement initiated by the association in 1869 and executed in 1870 encouraged kinfolk to acquire land adjacent to each other, underscoring the importance of familial dependency and support. Thus, neighbors were not only exclusively Dutch of select provincial origins - mostly from Zuid Holland ( 28 percent), Friesland ( 21 percent), and Gelderland ( 15 percent); they were also brothers, sisters, parents, children, in-laws, or cousins.

A few examples of this creation of neighborhoods by relatives illustrate this point. In section 32 of Holland Township the Van der Meers - Isaak and his sons Leendert and Dirkhomesteaded eighty-acre tracts. Isaak's three sons-in-law secured homesteads in nearby section 30. A brother-in-law of Isaak's two sons, who married Van den Bos sisters, also homesteaded in section 30, as did Isaak's two grandchildren, even though the latter two lacked legal standing for a claim since they were under 21. In section 18 Arie Van der Meide won the west half of the southwest quarter; his mother, who remained in Pella, got rights to the east half of the same quarter. In order to show improvement to both eighties to fulfill homesteading requirements, the farmstead buildings straddled the line between the two parcels, and the driveway followed the dividing line. The mother sold her 80 acres to her son in 1876 for four hundred dollars. The brothers Harke and Lubbert Boersma and

spatially compact and connected, never practiced that kind of closed, corporate agriculture or that degree of ethnoreligious insularity. Van Hinte, Netherlanders, 480 , also notes that buildings on the Sioux County Dutch farmsteads were detached in typical American fashion, not as in the Netherlands, where house and barn were often connected structures. 
their families settled in section 4 of future Floyd Township. Similarly, in section 4 of Nassau Township the Rysdam brothers, Wijnand and Gerrit, each took up homesteads. ${ }^{29}$

Beyond this kinship contiguity, other land transactions quickly began to fill in the territorial checkerboard. In 1870 Jelle Pelmulder and his son John and son-in-law Arie Werkhoven all homesteaded eighties in section 10 of Holland Township. Then in 1874 Jelle bought 120 acres in section 9 from the St. Paul and Sioux City Railroad for nine hundred dollars, or $\$ 7.50$ per acre. A second son-in-law, John Thomassen, also bought railroad land in section 9, indicating that farm expansion by purchase quickly focused on the extensive acres of railroad land available at prices no longer considered unreasonably expensive, especially in comparison to land prices in settled areas to the east. Already in 1871 several Dutch farmers arriving from Alto, Wisconsin, had acquired quarter-section tracts of railroad land in Holland Township at seven dollars per acre. Simultaneously, in Nassau Township, other Wisconsin Dutch purchased land from the Iowa Falls and Sioux City Railroad. Before moving, these farmers had sold land in Fond du Lac County, where prices averaged more than forty dollars per acre. This gave them a considerable investment advantage. ${ }^{30}$

AMID ALL THE FARM-MAKING, the town of Orange City was also to play an important role in the settlement, at first primarily as a symbolic focal point for the settlers rather than as a provider of essential services. The town's beginnings, however, were not auspicious; the pioneer farmers were initially preoccupied with their land and its produce. Nonetheless, some townsite development did take place in the spring of 1870 .

29. Noteboom, "Holland Township," 16-19; Transfer Books for Holland and Nassau Townships as they were configured in 1870, Sioux County Courthouse, Orange City.

30. Transfer Books for Holland and Nassau Townships; Van Hinte, Netherlanders, 476; Ninth Census of the United States, vol. 3, 335, for Wisconsin land prices. Most of the Wisconsin families originated from Gelderland and Zuid Holland provinces. 
Men marked out lots and roads, named some of the streets, and laid out a public square. But only one family lived in Orange City's solitary house that first year: carpenter Abraham Lenderink, his wife, and their son, emigrants from Zutphen, Gelderland, to Pella in 1858. This craftsman's presence was appropriate in a settlement that required much new construction; the colony's need for buildings offered as much opportunity for him as the unplowed land did for the farmers. In 1871 Henry Hospers, who had been in the Netherlands during the winter of 1870-71 recruiting emigrants to relocate in the new colony, arrived in Orange City to supervise construction of his general merchandise store, which also served as the post office. The town began to take shape during 1871 with the construction of an inn, a shoe repair shop, a barber shop, and a smithy as well as a few houses. Lenderink completed a school in August. By its early appearance, the school underscored the importance the Dutch settlers placed on the value of education. ${ }^{31}$

The enclave also focused on ethnoreligious affairs, with immediate attention to church meeting places. The historic factionalism between Reformed and Christian Reformed expressions of the Calvinist faith required the formation of not one but two religious bodies. During 1870 some pietists met informally in a sod meeting house on Martin Ver Heul's homestead in section 10 of Holland Township. In May 1871, 39 Dutch farmers formally organized a congregation that became the First Reformed Church of Orange City. At first they worshiped in the schoolhouse; in 1874, the congregation, by then numbering 265, built a permanent edifice for services with a seating capacity for 800 . They clearly envisioned growth. Meanwhile, in July 1871, twenty-four other Dutch coreligious, also nearly all farmers, formed the Christian Reformed Church and met in an available building. Both congregational meeting places

31. Van der Zee, Hollanders, 146; Van Hinte, Netherlanders, 478-79; Lucas, Netherlanders in America, 343; Nieuwenhuis, Siouxland, 110; Dyke, Story, 56-57. Lenderink's two-story house and the shoe repair shop reflected Old Country cultural persistence architecturally, for the shops took up the front of the lower story and the families' living quarters were behind and upstairs. 
made Orange City what historian Van Hinte has termed a "church village." 32

In the November 1872 election, county voters selected Orange City as the county seat. This confirmed by franchise what Dutch raiders had acquired by force in January from the village of Calliope in western Sioux County, where a small clique of American politicos had for several years mismanaged local government. By physically seizing and transferring official county records from one town to another, the Dutch-Americans added Sioux County to the long list of Iowa counties that experienced "county seat wars." Their action also enhanced Orange City's municipal prominence. ${ }^{33}$

By 1874 the town included a building for county offices, a school, two church organizations, five stores, a law office, a land office, two "hotels," a banking service operated by Hospers, and forty residences. Finally, in June 1874, Hospers began publication of a weekly Dutch language newspaper in the village. De Volksvriend (The People's Friend), provided local news and served as a vehicle to advertise the Dutch colony and enlarge the ethnic settlement. Along with these developments, the town's population rose gradually from 24 in 1871 to 175 in $1874 .^{34}$

The village was a country place. Although town growth was certainly not inconsequential, especially since it included the vital concerns of school and church for the ethnoreligious community, it was not an instant boom town of legendary "frontier" proportions. Nevertheless, Orange City evolved sequentially and structurally from general service facilities to religious and

32. Lucas, Netherlanders in America, 343; Van Hinte, Netherlanders, 481-82, 50917, 1062n; Nieuwenhuis, Siouxland, 110-13, 247; Dyke, Story, 140-41, 164-65; Gerald F. De Jong, "Four Generations of a Dutch America Community," in Mark Boekelman and Herman Gansevoort, eds., Dutch Immigration to North America (Toronto, 1982), 226.

33. Van Hinte, Netherlanders, 484-88; Nieuwenhuis, Siouxland, 54-58; Dyke, Story, 129-38; Van der Zee, Hollanders, 235-38. The most detailed examination of the Dutch political response to the schemes of the so-called Johnson-Stone Ring is found in Ken Hausen, Calliope (Marceline, MO, 1982).

34. Van Hinte, Netherlanders, 478-79; Lucas, Netherlanders in America, 344; Nieuwenhuis, Siouxland, 113-14; Van der Zee, Hollanders, 179. Sources vary slightly on Orange City's population statistics. 
educational needs and on to administrative and political functions. All aspects of this maturation reflected efforts at institutional replication and cultural continuity. However rudimentary these gestures, the Dutch settlers were striving for community completeness that would meet basic needs, maintain social order, ensure literacy, extend religious ideals, preserve moral authority, and transmit values to future generations.

These community goals remained fixed even as farmers established property ownership within the federal land system and produced agricultural commodities beyond subsistence to sell and ship via local railroads. While the fabric of community was being woven, the rural ethnic enclave was becoming integrated into a regional market economy: the Dutch farmers' goals included making a living as well as preserving a way of life. Daily, they focused primarily on the open countryside of farmstead and field. Jacob Koster, who moved from Greenleafton, Minnesota, in October 1871 with 32 persons in five ox-drawn wagons, homesteaded in section 4 of West Branch Township. In April 1873 a letter he published in De Hope, a Reformed Church periodical published in Holland, Michigan, captured the essence of this farming settlement.

Truly this is country such as one can desire. It is not too much to call it a Canaan. The soil is very fertile, literally everything will grow on it. The surface is rolling. We have no sand or hills. There are no swamps, no trees that must be cleared away, no stumps that impede operations, no heavy clay or catholes. The ground is ready for the plow. The farmers on the average thresh twenty bushels of wheat per acre, fifty to sixty bushels of oats, about the same amount of corn, and two hundred bushels of potatoes, and sometimes more. I own a farm of 160 acres. I have broken 100 acres, which now are under the plow, and, if the Lord wills it, I hope to break the rest this summer. ${ }^{35}$

Settlement on the unpeopled grasslands of the early 1870 s may suggest geographic isolation from more settled environs bound together by transportation networks and intercommunity commerce. Indeed, being an island enclave on a prairie sea may

35. The quote from De Hope, 9 April 1873, is reproduced in Lucas, Netherlanders in America, 345; Dyke, Story, 123. 
have contributed to a sense of ethnic territoriality, at least initially. Some modern scholars who seem inured to urban density have, however, made too much of this element of isolation. ${ }^{36}$ Within three years of the colony's founding, a railroad connector was available to the Sioux County Dutch, providing both freight and passenger service. The enclave was distant from many places but never isolated, and always an ethnic and kinship bond tethered Sioux County to Marion County. Moreover, its territorial integrity, although in part a function of geography, was defined more by social and cultural boundaries: its Dutchness, language, and religion, and the strength of its folkways, as well as its "monopoly" on the local land market. At the same time, these traits, which were the territory's cordage, deterred an influx of non-Dutch outsiders who would have diluted the ethnocultural character of the community.

THE DUTCH-AMERICANS expanded their rural ethnic territory from its 1870 checkerboard core as they filled in vacant sections to form an even more compact landscape design in all directions. Dutch settlers began to venture northwesterly beyond the West Branch creek in 1873. Already in 1871 a post office had been located on a stage line running northward out of Sioux City at a site that would later become the village of Sioux Center. But the platting of the town had to wait until 1881 , when sufficient population density in that vicinity gave urgency to founding an additional rural service center to cater to the Dutch enclave's northwest sector. Sioux Center and Orange City thus came to be ten miles apart by section line roads, confirming the classic geographical dictum that the typical spatial frequency of midwestern towns in the nineteenth century equaled the distance of a half-day's wagon haul for farmers. The settlers taking up land toward Sioux Center in the western third of Holland Township (range 45 of township 95), which became West Branch Township in 1876, were Dutch-Americans

36. See, for example, Carol K. Coburn, Life at Four Corners: Religion, Gender, and Education in a German-Lutheran Community, 1868-1945 (Lawrence, KS, 1992), introduction; but also compare Loewen, Family, Church, and Market, chap. 4, in which he, too, qualifies the isolation factor. 
from Muscatine County, Iowa; Fillmore County, Minnesota; and Fond du Lac and Sheboygan Counties, Wisconsin. A few were immigrant families from the Netherlands originating in Gelderland and Friesland. In May 1877 they organized a small Reformed congregation at Sioux Center, separating themselves from the Orange City church and establishing another ethnoreligious magnet within the colony. ${ }^{37}$

When the St. Paul and Sioux City Railroad was completed in October 1872, corporate officials located two train stations in Sioux County to serve the settlers. North Orange (Hospers) and East Orange (Alton) drew farm-to-market business eastward toward the rail line that paralleled the Floyd River. For another decade Orange City failed to secure direct rail service that provided essential regional market connections, yet as the "church town" for the enclave, it survived what was often a fatal blow to new towns in frontier America. As commercial stations, Hospers and Alton evolved into "elevator towns," again to use Van Hinte's lexicon, with granaries eventually rising along the railroad tracks. Van Hinte's distinction between church villages on the high prairie lands and elevator villages in the river valleys, which he used to explain the comparatively slow, homogeneous development of the former and the more rapid, heterogeneous expansion of the latter, is instructive, but requires some qualification in the case of the Sioux County villages.

The evolution of Hospers was based on both commerce and religion. Although a depot site, it emerged initially as a German village; a Catholic parish formed there in 1872. Not until 1886 did the Dutch establish a Reformed Church in Hospers. Likewise, Alton, platted in 1875, served the German Catholics who lived east of town; they held their first mass in the railroad village in 1873. Although the local Dutch folk organized a Reformed congregation in Alton in 1877, they waited until 1881 to build a church. Despite their similarities, Hospers grew slowly while Alton displayed the vigor of a marketplace town.

37. Nieuwenhuis, Siouxland, 155, 80; Lucas, Netherlanders in America, 348-49; Mike vanden Bosch, ed., A Pocket of Civility: A History of Sioux Center (Sioux Falls, SD, 1976); John C. Hudson, "The Plains Country Town," in Brian W. Blouet and Frederick C. Luebke, The Great Plains: Environment and Culture (Lincoln, NE, 1977), 99-118. 
In 1880 Hospers's population was 51; Alton's was 144. (By comparison, Orange City's was 319). In the two villages along the Floyd River, no singular commercial orientation as an elevator town explains their development. Rather, a mix of commerce and dual ethnoreligious foundations made them more culturally heterogeneous with a more complex local history. And in Alton, which served as the railroad service center for the Dutch farmers in its trading zone, competitive boosterism among its town leaders made it a threat for at least two decades to Orange City's claim to county leadership. Still, Alton never rivaled Orange City as the ethnocultural center of the Dutch colony, and the church town's growth was not eclipsed by that of the elevator town. ${ }^{38}$

Village formation and the continued influx of farm families seemed to ensure inexorable growth and expansion for the Dutch enclave. The special Iowa census of 1873 numbered 163 farm families in as many residences in Holland Township and 92 farm households in Nassau Township. Together with the 27 families residing in Orange City, this totaled 1,506 persons. ${ }^{39}$ By 1873 a writer in De Hope stated that 400 families and 500 houses existed in the Dutch colony as a whole. Orange City now had seven stores, Hospers five, and Alton four. Eleven schools, three post offices, and several roads and bridges had been built. According to the observer, the colony extended 18 miles from east to west and 14 from north to south, although land records suggest a slightly smaller territory of 14 by 13 miles. Farmland sold for eight to twelve dollars per acre. In 1875 another letter in De Hope averred that the settlement contained at least 450 families and 17 schoolhouses, while 200,000 bushels of wheat had been raised on 30,000 acres of improved land the previous year. Meanwhile, according to the state census of 1875, the colony witnessed a bumper crop of babies in

38. Nieuwenhuis, Siouxland, 112, 127-28, 168-73; Lucas, Netherlanders in America, 349; Van Hinte, Netherlanders, 502-3, 509-17; Dyke, Story, 149, 323-28, 323-64. For town population figures in 1880 , see the federal manuscript population census for that year.

39. Van Der Zee, Hollanders, 148, 180; Lucas, Netherlanders in America, 340; Nieuwenhuis, Siouxland, 66, 110; Van Hinte, Netherlanders, 480, 482; Census of Iowa for 1873. 
1874, further testimony to a burgeoning settlement of family units. ${ }^{40}$

Other evidence confirms these impressionistic descriptions of community growth. In 1874 the eastern third of Holland Township (range 43 of township 95) was reorganized into Floyd Township. By 1876 East Orange and Sherman Townships had been formed out of the eastern and western thirds of Nassau Township. These latter two entities, together with the three political divisions created from Holland Township, now turned the Dutch colony into a five-township enclave. Only near the end of the decade did a few Dutch-Americans begin to buy parcels of land in Township 96 to the north, which was known locally during the 1870 s as a gaming area for speculators. ${ }^{41}$

During that decade the ethnic territory had steadily enlarged from its initial core of 1870. Maps 3, 4, and 5 show the precise spatial expansion of the Dutch enclave section by section for three-year periods ending in 1873, 1876, and 1879. The range of years on each section indicates the time it took to transform the prairie to farmland through privatization: the first date is the date of initial settlement in that section; the second identifies when all the land in that section had been privatized. In some cases the land may not have been immediately put to the plow. It may have served as pasture or hay land for a year or two, or it may have been held for speculative purposes for a short time. Nevertheless, the maps based on the records of land transactions provide reasonable images of the diffusion of the ethnic territory.

40. Lucas, Netherlanders in America, 348; Nieuwenhuis, Siouxland, 69. Van Hinte Netherlanders, 502-3, says that in 1875 there were 468 families totaling 2,500 Dutch folk in the colony. The Iowa census takers in 1875 found 363 families and 1,835 persons in the Holland-Nassau-Floyd Township area. Some of these, perhaps about 50 families or 250 persons (using an average family size of 5), were German Catholics. Note also that the Iowa census for 1875 indicated that total wheat production in 1874 was 154,666 bushels for the Holland-NassauFloyd township area. The Dutch boosters rounded up to 200,000 bushels! On the other hand, it is noteworthy that the profusion of schools did not depend on revenue from selling land in section 16 of each local township, since those sections did not begin producing revenue until the $1880 \mathrm{~s}$.

41. On Township 96, see Dyke, Story, 262-63. Land records show that 14 Dutch-Americans bought tracts located in ten sections of Township 96 prior to 1880. In 1879 John Van den Berg was the first to begin farming north of Holland Township in section 34 of Welcome Township. 
MAPS 3 AND 4

INITIAL DUTCH OCCUPANCY BY SECTION, 1871-1873 (TOP) AND 1874-1876 (ВОTTOM)
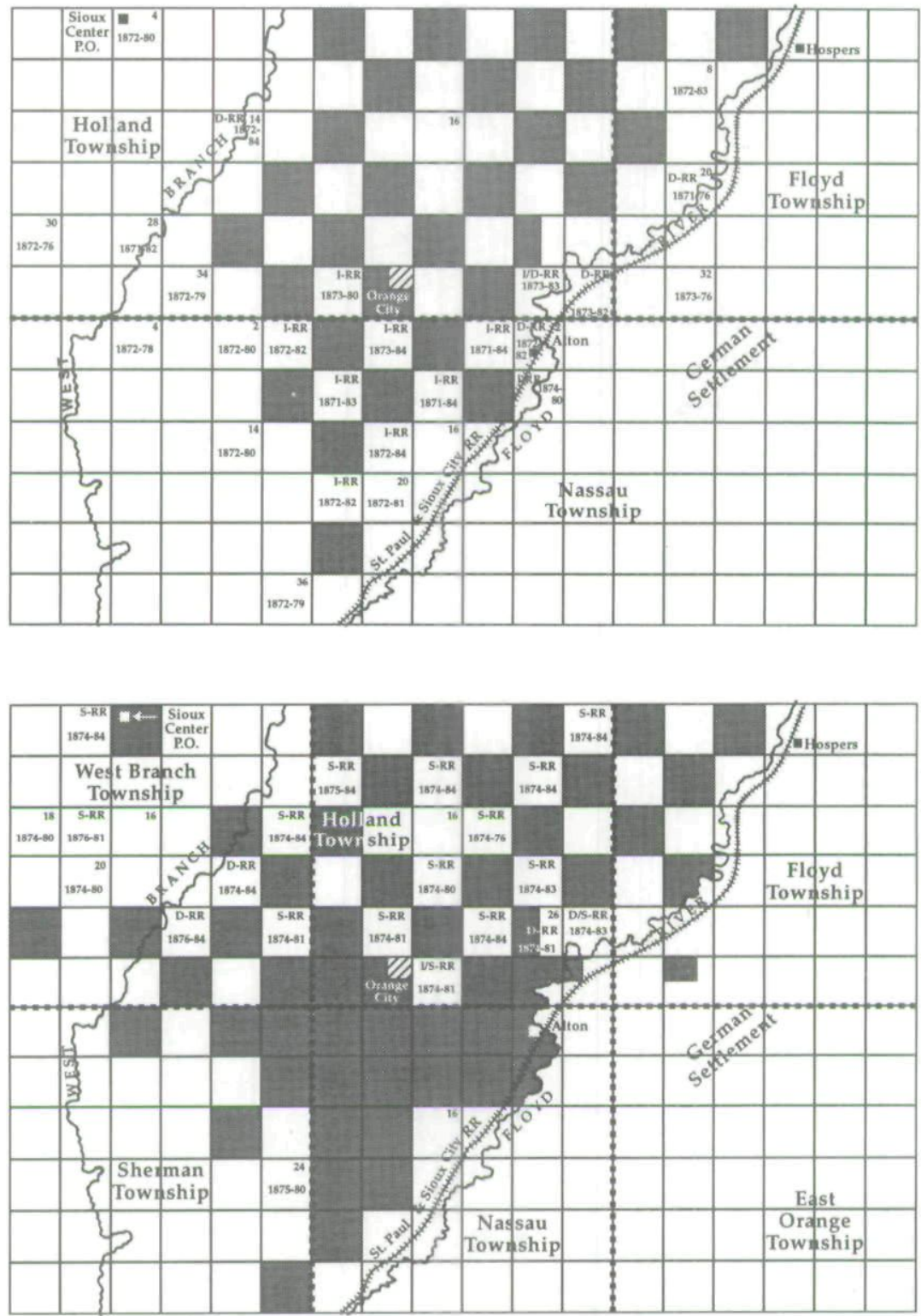

S-RR St. Paul \& Sioux City RR

D-RR Des Moines Valley RR

I-RR Iowa Falls and Sioux City RR 


\section{MAP 5}

INITIAL DUTCH OCCUPANCY BY SECTION, 1877-1879

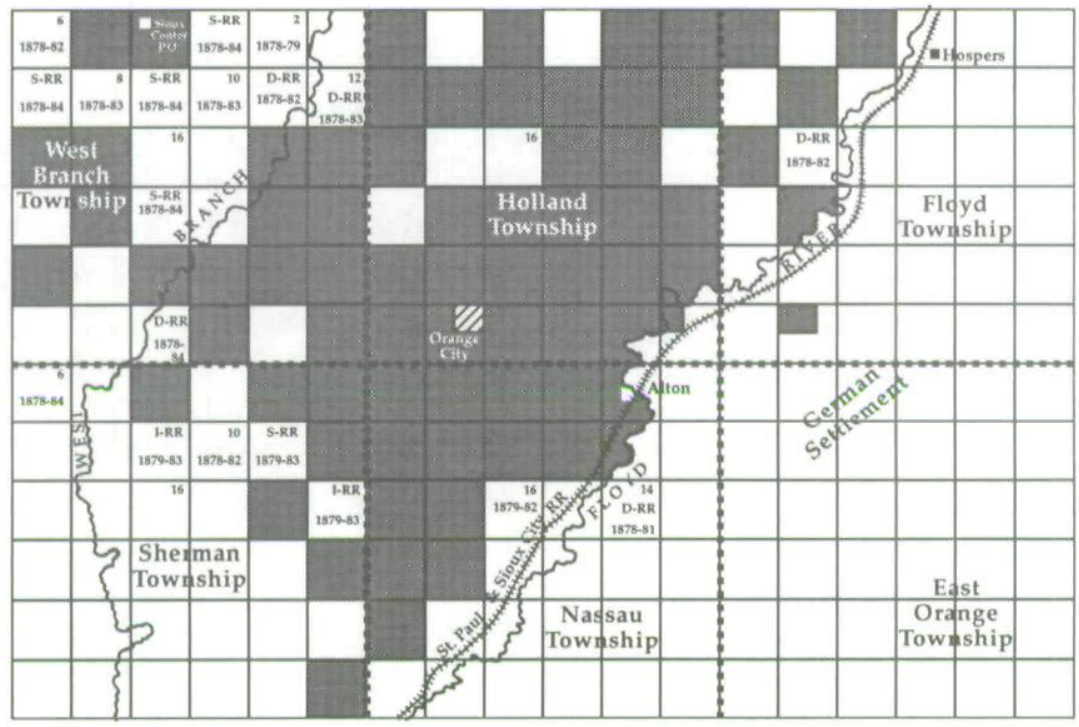

S-RR St. Paul \& Sioux City RR

D-RR Des Moines Valley RR

I-RR Iowa Falls and Sioux City RR

SOURCES: Transfer Books, Sioux County Courthouse, Orange City; Swierenga, comp., Dutch Emigrants; idem, Dutch Households in U.S. Population Censuses 1850, 1860, 1870: An Alphabetical Listing by Family Heads, 3 vols. (Wilmington, DE, 1987). This mapping exercise was informed in part by John C. Hudson, Making the Corn Belt: A Geographical History of Middle-Western Agriculture (Bloomington, IN, 1994).

This decade-long spatial diffusion was not a matter of serendipity. Just as initial settlement in 1870 reflected a rational acquisition of available "free land," so subsequent expansion is largely explained by the influence of supply-side factors. From 1871 through 1873 Dutch-Americans secured more land from the public domain or from the Iowa Falls and Sioux City Railroad and the Des Moines Valley Railroad. As a result, tracts of railroad land primarily in Nassau Township were privatized first. St. Paul and Sioux City Railroad land located in Holland Township was not marketable until March 1874, when Iowa's governor finally certified that the land previously held in trust for the railroad by the state was legally conveyed to the corpo- 
ration because all its trackage through northwest Iowa was complete. Thus, only during and after 1874 could Dutch-Americans begin to buy and aggressively occupy these railroad sections in Holland Township and thereby expand their enclave to the north and northwest, as the maps indicate. From 1874 to 1879 no new Iowa Falls and Sioux City sections went on the market, although buyers continued to purchase additional parcels within partially occupied railroad tracts. Presumably the St. Paul and Sioux City land, much of it held for a few intermediary years by absentee land speculators, was marketed more effectively than the Iowa Falls and Sioux City property, almost all of which passed directly from the railroad company to Dutch buyers. In this way alert entrepreneurial land jobbers captured much of the Dutch-Americans' money. A few more sections of the Des Moines Valley Railroad land as well as more new sections of the public domain mainly in West Branch Township came under Dutch privatization after 1874 , too. ${ }^{42}$

By 1879 the Dutch enclave entailing 103 sections configured a wedge-like pattern with the point in section 36 of Sherman Township and the $\mathrm{V}$ extending northeast and northwest up to and just beyond the northern borders of West Branch, Holland, and Floyd Townships. Only a few scattered sections designated as school land or specific parcels of railroad land that were encumbered by speculators' litigation broke the solid contiguity of the Dutch colony in Sioux County. This was rural ethnic clustering in bold relief.

Although expansion was the dominant theme of the colony, the years from 1873 through 1879 were seven long lean years that combined national economic depression with regional droughts, grasshopper invasions, sudden torrential rains, grueling winters, and even prairie fires. The severity of the infamous grasshopper infestation in the local area was particularly serious. Statistics on crop yields for 1874 in the Dutch-occupied townships of Sioux County show a dramatic drop in the yield of

42. Lokken, Iowa Public Land, 239, 251-54, 258-59; Transfer Books, Sioux County Courthouse, Orange City; Bogue, From Prairie to Cornbelt, 40-42. Some of the absentee land speculators whose names (all non-Dutch) appeared regularly in the land records were Adrian Iselin Jr., Horace E. Thompson, Elliot C. Davidson, John N. Hazard, Simon Toussaint, and Robert H. Ives. 
principal crops. In 1873 Jacob Koster had commented that wheat generally yielded about 20 bushels per acre and oats and corn about 50 to 60 bushels per acre. But in 1874 farmers reaped only 12 bushels of wheat per acre, 12 of oats, 17 of barley, 6 of rye, and 6 of corn. Recurrent harvest failures and other calamities made some Dutch settlers wonder at times if they had made a mistake, and some residents understandably gave up. Historian Van Hinte estimated that about one-third of the Dutch populace left Sioux County because of the grasshoppers, a figure that remains unverifiable. ${ }^{43}$

The adversities, however, did not cause a serious interruption in the pace of the enclave's growth, fed in part by natural reproductive increases. Colony leaders also exhorted beleaguered farmers to prevail in the face of trials. Fortitude and faith, as well as a strong dose of Dutch stubbornness, kept the majority of farmers on the land, not unlike their European forebears who pushed back the sea for centuries despite periodic flooding. Moreover, an excellent harvest in 1875 interrupted the blighted years and rekindled the folklore of hope that had, for some, momentarily faltered. Fifty-eight of the 75 original homesteaders of 1870 still remained ten years later - an impressive persistence rate of 77 percent. ${ }^{44}$ Unfortunately the manuscript returns for

43. Van der Zee, Hollanders, 160-78, 183-85, provides the most thorough description of the tribulations and discusses the alternating discouragement and renewal that occurred from season to season. See also Lucas, Netherlanders in America, 345-46; Van Hinte, Netherlanders, 390-93; Dyke, Story, 178-88; Nieuwenhuis, Siouxland, 79; "Joe Rexwinkle's Nassau Township, Sioux County," in Henry S. Lucas, ed., Dutch Immigrant Memoirs and Related Writings, 2 vols. (Assen, Netherlands, 1955), 2:250-54; Census of Iowa for 1875. Van Hinte's estimate of population decline is found in Netherlanders, 497.

44. Federal Manuscript Population Censuses for 1870 and 1880 . See generally the discussion on farm persistence in Bogue, From Prairie to Cornbelt, 25-27. On Dutch farmer's persistence, see Richard L. Doyle, "The Socio-Economic Mobility of the Dutch Immigrants to Pella, Iowa, 1847-1925" (Ph.D. diss., Kent State University, 1982), 103-9. On other Dutch persistence, see David Gordon Vanderstel, "The Dutch of Grand Rapids, Michigan: A Study of Social Mobility in a Midwestern Urban Community, 1850-1870" (M.A. thesis, Kent State University, 1978), 67; Gordon W. Kirk, The Promise of American Life: Social Mobility in a Nineteenth-Century Immigrant Community, Holland, Michigan, 1847-1894 (Philadelphia, 1978), 51-54; Swierenga, "Dutch International Migration and Occupational Change: A Structural Analysis of Multinational Linked Files," in Ira A. Glazier and Luigi De Rosa, eds., Migration across Time 
the Iowa census of 1875 no longer exist to measure persistence from that year to 1880 . Nonetheless, it is clear that no syndrome of "In God we trusted, in Kansas we busted" befell the northwest Iowa Dutch.

THE MANUSCRIPT CENSUS of 1880 provides a final portrait of the enclave after ten years of persevering (see tables 3 , 4 , and 5). In 1880 Netherlands-born residents or first-generation immigrants constituted 46 percent of the Dutch enclave in the five Sioux County townships. Second-generation immigrants native-born persons of Dutch stock - came from several states. Dutch enclaves in Michigan, Wisconsin, and Illinois were important population sources for the colony, but Iowa-born Dutch accounted for 44 percent of the settlement's population, and the largest cohort of first- and second-generation Dutch in northwest Iowa came there by way of the "mother colony" of Pella. Of a total of 441 households, at least 160, or 36 percent, had previously resided in Marion County or adjacent Mahaska County. In general, emigration from the Netherlands ebbed between 1870 and 1880. During the 1870s the foreign-born Dutch population in Iowa increased by only 230 , from 4,513 to. 4,743 . Some of those settled in counties other than Sioux, but at least 157 new Dutch immigrants from 27 households found a mooring in Sioux County during the 1870s. Of these 157, 87, or 55 percent, came from Gelderland; 39, or 25 percent, emigrated from Friesland; and the remaining 31, or 20 percent, originated from Zuid and Noord Holland, Zeeland, and Overijssel. Significantly large migration streams from the Netherlands directly to Sioux County, however, had to wait for the next decade. ${ }^{45}$

and Nations: Population Mobility in Historical Contexts (New York, 1986), 95124, esp. 108. For a discussion of recent studies finding more rural population stability than turnover, see Hal S. Barron, "Rediscovering the Majority: The New Rural History of the Nineteenth-Century North," Historical Methods Newsletter 19 (1986), 141-52.

45. I derived the immigrants' origins from analysis of the Federal Manuscript Population Census for 1880; Swierenga, comp., Dutch Emigrants to the United States; and idem, Dutch Households in U.S. Population Censuses. See also Swierenga, "Dutch International Labour Migration"; idem, "Local Patterns of Dutch Migration"; Van der Zee, Hollanders, 179. The gains by township were: Hol- 
TABLE 3

POPULATION COMPOSITION IN SIOUX COUNTY FOR SELECTED TOWNSHIPS IN 1880

\begin{tabular}{lrrrrr}
\hline Township/Town & Total & \multicolumn{2}{c}{ Dutch Stock } & \multicolumn{2}{c}{ Non-Dutch } \\
& & N & \multicolumn{1}{c}{$\%$} & N & $\%$ \\
\hline Holland & 701 & 698 & 99.6 & 3 & 0.4 \\
Orange City & 320 & 289 & 90.3 & 31 & 9.7 \\
West Branch & 420 & 402 & 95.7 & 18 & 4.3 \\
Floyd & 438 & 175 & 40.0 & 263 & 60.0 \\
Hospers & 51 & 13 & 25.5 & 38 & 74.5 \\
Nassau & 596 & 344 & 57.7 & 252 & 42.3 \\
Alton & 144 & 88 & 61.1 & 56 & 38.9 \\
Sherman & 336 & 213 & 63.4 & 123 & 36.6 \\
$\quad$ Total & 3,006 & 2,222 & 73.9 & 784 & 26.1 \\
\hline
\end{tabular}

SOURCE: Federal Manuscript Population Census for 1880.

By 1880 Dutch farmers were almost exclusively filling up Holland and West Branch Townships; they had privatized about 77 percent of the land in the former and about 41 percent in the latter. In the other three townships the Dutch shared the land with other farmers living beyond the periphery of the enclave. But nowhere had population growth resulted yet in 100 percent occupancy of the land. The average-sized Dutch farm of almost 120 acres reflected a range from the 400 acres owned by Arent van Wechel, who relocated from Wisconsin to Nassau Township,

land, 56 (Gelderland, 44; Zuid Holland, 8; Friesland, 3; Noord Holland, 1); Nassau, 54 (Gelderland, 25; Friesland, 16; Noord Holland, 9; Zeeland, 4); West Branch, 18 (Gelderland, 17; Friesland, 1); Floyd, 15 (Friesland, 12; Overijssel, 3); and Sherman, 14 (Friesland, 7; Overijssel, 6; Gelderland, 1). Admittedly, these counts do not enumerate those Netherlands-born residents who died between census takings or who stayed only briefly in the state. Many intradecade relocators are lost to history, but a few cases in Sioux County are known. In 1872 Cornelius Hornstra immigrated to Orange City with his wife and nine children. Fred and Mrs. Hornstra and Henry and Rachel Dykstra came that same year to Wisconsin but moved to Sioux County in 1873. In 1874 all three couples, related by blood or marriage, moved to Bon Homme County, South Dakota, to found another Dutch enclave. In 1869 Ulbe Wijnia, his spouse, Teatske Bootsma, and their eight children immigrated to Pella, but joined the 1870 pioneers to Sioux County. In 1878 they, along with the household of Rein Talsma, relocated to Bon Homme County. All of these were originally from the province of Friesland. See Beltman, Dutch Farmer in the Missouri Valley, 113; 100 Years of God With Us: Emmanuel Reformed Church, Springfield, South Dakota, 1888-1988 (Freeman, SD, 1988), 5-7. 
TABLE 4

PLACE OF BIRTH OF DUTCH RESIDENTS IN 1880

IN SELECTED SIOUX COUNTY TOWNSHIPS BY COUNTRY OR STATE

\begin{tabular}{lrrrrrrrr}
\hline Township/Town & Neth. & IA & MI & WI & IL & $\begin{array}{l}\text { Other } \\
\text { States }\end{array}$ & $\begin{array}{l}\text { At } \\
\text { Sea }\end{array}$ & Total \\
\hline Holland & 277 & 361 & 20 & 18 & 10 & 11 & 1 & 698 \\
Orange City & 120 & 142 & 16 & 5 & 2 & 4 & - & 289 \\
West Branch & 205 & 142 & 20 & 19 & 5 & 10 & 1 & 402 \\
Floyd & 94 & 64 & 5 & 6 & 4 & 1 & 1 & 175 \\
Hospers & 11 & 2 & - & - & - & - & - & 13 \\
Nassau & 175 & 120 & 26 & 14 & 6 & 3 & - & 344 \\
Alton & 41 & 36 & - & 4 & 2 & 5 & - & 88 \\
Sherman & 95 & 102 & - & 9 & 1 & 6 & - & 213 \\
$\quad$ Total & 1,018 & 969 & 87 & 75 & 30 & 40 & 3 & 2,222 \\
\hline
\end{tabular}

SOURCE: Federal Manuscript Population Census for 1880.

to the 10 acres of Bote Smits, who came from Groningen in 1867 by way of Pella and also settled in Nassau. Of the total of 359 farmers, 66 , or 18 percent, were tenants. ${ }^{46}$

Like other early frontiers, the local socioeconomic structure measured by land tenure and use was not a democratically equitable one, but neither was it disproportionately inequitable. ${ }^{47}$ Of the 65 Dutch farmers in Nassau Township, for example, four farmers, the upper 6 percent of landowners, owned farms larger than 160 acres, or 14 percent of Dutch-held land. Seventeen farmers, or 26 percent, fell in the next cohort of occupants, all operating quarter sections, or 38 percent of the land. Twentyeight others, or 43 percent, farmed the modal size of eighty acres, or 31 percent of the land. Nine resided on farms ranging from 50 to 130 acres (but not on eighties). Six, or 9 percent,

46. The statewide tenancy rate for Iowa in 1880 was slightly less than 24 percent. Federal Manuscript Agricultural Census for 1880. See also Bogue, From Prairie to Cornbelt, 62.

47. Information for this paragraph derives from the Federal Manuscript Agricultural Censuses for 1870 and 1880 . For a comparison on socioeconomic mobility among the Dutch, but using different indicators, see Swierenga, "Dutch International Migration and Occupational Change," 106-120, which includes summaries of data from the studies by Richard L. Doyle, Gordon W. Kirk Jr., and David Gordon Vanderstel on the Dutch in Pella, IA, Holland, MI, and Grand Rapids, MI. 


\section{TABLE 5}

FARMERS AND FARMS IN SIOUX COUNTY FOR SELECTED TOWNSHIPS IN 1880

\begin{tabular}{lccccc}
\hline Townships & \multicolumn{2}{c}{ Number of Dutch Farmers } & $\begin{array}{c}\text { Number of } \\
\text { Non-Dutch } \\
\text { Farmers }\end{array}$ & $\begin{array}{c}\text { Dutch Farms } \\
\text { (average size/ } \\
\text { total acres) }\end{array}$ \\
\hline Holland & 99 & 40 & 139 & 1 & $127 / 17,685$ \\
West Branch & 66 & 8 & 74 & 2 & $129 / 9,510$ \\
Floyd & 34 & 2 & 36 & 43 & $115 / 4,134$ \\
Nassau & 56 & 9 & 65 & 20 & $110 / 7,164$ \\
Sherman & 38 & 7 & 45 & 31 & $99 / 4,451$ \\
\hline \multicolumn{1}{c}{ Total } & 293 & 66 & 359 & 97 & $120 / 42,944$ \\
\hline
\end{tabular}

SOURCE: Federal Manuscript Agricultural Census for 1880.

owned modest forty-acre farms, or 3 percent of the land, and one occupied ten acres. Further, of the 65 farmers, nine, or 14 percent, were tenants, but at least four of these were sons (more may have been sons-in-law) living on land adjacent to their landowning fathers and were, in effect, owners-in-prospect. For comparison, of 53 of the 58 pioneers of 1870 who still resided in Sioux County in 1880 and for whom land ownership could be determined, 16, or 30 percent, continued to reside on 80 acres, but the other 37 , or 70 percent, had increased their landholdings. The average size of their farms had risen to 171 acres; the modal size was a quarter section. Dirk Van den Bos, who owned 400 acres, topped this group after ten years of farming in Sioux County.

Representative agricultural data from Nassau Township illustrates the scale and nature of diversified, commercial farming practiced by the Dutch and underscores that farmers, although expanding operationally, had not yet evolved fully to a more focused Cornbelt pattern of corn-hog production (see table 6). Wheat was still the most popular crop in this northwest Iowa subregion that was no longer a frontier. ${ }^{48}$

48. For a case study of a Dutch immigrant family who settled in Nassau Township in 1877 that details farm operations at the individual level, see Beltman, "Ethnic Persistence and Change." 
TABLE 6

AGRICULTURAL STATUS OF DUTCH FARMERS

IN NASSAU TOWNSHIP, 1880

\begin{tabular}{lr}
\hline Acres of land (improved) & 83.7 \\
Acres of land (unimproved) & 26.5 \\
Total acres of land & 110.2 \\
Value of land and buildings & $\$ 1,547$ \\
Value of machinery & $\$ 227$ \\
Value of livestock & $\$ 387$ \\
Value of agricultural production (1879) & $\$ 244$ \\
Horses & 3.1 \\
Milk cows & 2.5 \\
Other cattle & 2.0 \\
Pigs & 30.6 \\
Chickens & 53.5 \\
Acres of wheat & 41.2 \\
Acres of corn & 28.2 \\
Acres of oats & 9.1 \\
Acres of potatoes & 1.0 \\
Acres of barley $(\mathrm{N}=37)$ & 7.0 \\
Acres of flax $(\mathrm{N}=15)$ & 6.3 \\
\hline
\end{tabular}

SOURCE: Federal Manuscript Agricultural Census for 1880.

NOTE: All figures represent the average per farm value $(\mathrm{N}=65)$. Cf. table 2.

BETWEEN 1870 AND 1880 the countryside between the Floyd River and its West Branch underwent appreciable change. Farms and villages, houses and barns, fences and roads occupied the landscape to realign the natural contours of the unbroken prairie into the segmented gridwork of farmsteads and fields that conformed to the required land survey system. Within this general rearranged pattern of land use was another configuration. A discrete ethnic territory containing a distinct ethnic people was identifiable, setting a portion of the land and its populace apart from the larger area and inhabitants. The Dutch came to northwest Iowa in 1870, pursued a conscious strategy to possess the land, and expanded their land base over time as circumstances and resources permitted. Their enclave reflected the selective migration of rural folk who created a Calvinist community devoted to family farming and individualized land ownership. This rural ethnic group transplanted the necessary social and institutional forms to sustain their cultural identity and support a viable community, and the rail system soon integrated them into the commercial agricultural economy of the state and region. 
Community and market were not antithetical. ${ }^{49}$ By 1880 another enclave of Dutchness was firmly rooted in the Midwest. One hundred and twenty-five years later that enclave still flourishes, testifying to the persistence of ethnic territoriality and ethnic identity in rural America.

49. For a bibliographical introduction to the sizable literature on the community vs. market debate, see Barron, "Rediscovering the Majority," 141-52. 
Copyright of Annals of Iowa is the property of State of Iowa, by \& through the State Historical Society of Iowa and its content may not be copied or emailed to multiple sites or posted to a listserv without the copyright holder's express written permission. However, users may print, download, or email articles for individual use. 